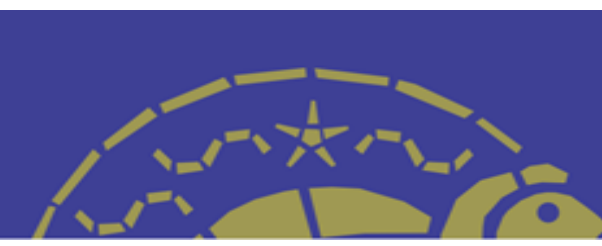

\title{
SCIENTIFIC COMMUNICATION ABOUT THE DISTRIBUTION OF INSECT BOXES IN SCHOOLS: REPORT ON EXPERIENCE
}

\author{
Manuela Kich Wegener \\ Instituto Federal de Educação, Ciência e Tecnologia Farroupilha \\ manuelakwegener@gmail.com \\ Camila Werbes Wesner \\ Instituto Federal de Educação, Ciência e Tecnologia Farroupilha \\ camilawesner@hotmail.com \\ Gustavo Pedroso de Moraes \\ Instituto Federal de Educação, Ciência e Tecnologia Farroupilha \\ gugamoraes.gm@gmail.com \\ Gerson Azulim Muller \\ Instituto Federal de Educação, Ciência e Tecnologia Farroupilha \\ gecoazul@hotmail.com
}

\begin{abstract}
We report here the experience in 2015 of a group of visiting students from the Farroupilha Federal Institute, who assembled and distributed insect boxes in public schools of municipalities in the northwestern region of the state of Rio Grande do Sul, Brazil. This activity was motivated by the observation that science laboratories at these schools lacked materials to use in laboratory practical in entomology. At the end of the project, the visiting students benefitted by experiencing a different school environment, and the schools gained more teaching materials to be used in laboratory classes in the field of biological sciences.
\end{abstract}

Keywords: Biology. Insects. Laboratories.

\section{DIVULGAÇÃo CIENTÍFICA A PARTIR DA DISTRIBUIÇÃO DE CAIXAS ENTOMOLÓGICAS EM ESCOLAS: UM RELATO DE EXPERIÊNCIA}

Resumo

Neste relato de experiência são apresentadas atividades realizadas no ano de 2015 por um grupo de alunos extensionistas do Instituto Federal Farroupilha, que montaram e distribuíram caixas entomológicas em escolas públicas de municípios da região noroeste do estado do Rio Grande do Sul. Essa atividade foi motivada pela deficiência observada nos laboratórios de ciências das escolas em relação à falta de material para ser utilizado em aulas práticas de entomologia. Ao final do projeto de extensão, foram gerados benefícios para os alunos extensionistas, que puderam vivenciar uma realidade escolar diferente da sua, e para as escolas, que tiveram um incremento de material didático para ser utilizado em aulas práticas na área de ciências biológicas.

Palavras-chave: Biologia. Insetos. Laboratórios.

\section{DIVULGACIÓN CIENTÍFICA A PARTIR DE LA DISTRIBUCIÓN DE CAJAS ENTOMOLÓGICAS EN ESCUELAS: RELATO DE EXPERIENCIA}

\section{Resumen}

En este relato de experiencia son presentadas actividades hechas en el año 2015 por un grupo de alumnos de extensión de Instituto Federal Farroupilha, que armaron y distribuyeron cajas entomológicas en escuelas públicas de ciudades de la región noroeste de Río Grande del Sur. Esa actividad se originó de la deficiencia observada en los laboratorios de ciencias de las escuelas en relación a la falta de materiales de utilización en clases prácticas de entomología. Al final del proyecto de extensión, fueron generados beneficios para los alumnos extensionistas, que han podido vivir una realidad escolar distinta de la suya, y para las escuelas, que han agregado material de apoyo didáctico para ser utilizado en clases prácticas en el área de ciencias biológicas.

Palabras-clave: Biología. Insectos. Laboratorios. 
Scientific communication about the distribution of insect boxes in schools: report on experience

\section{INTRODUCTION}

We live in a technological and scientific world where science has a social nature, since its understanding and application is essential for the technological and economic development of a country (BROOKS, 1994; ZANCAN, 2000). In Brazil, the scientific cultivation of the population is at a level far below that acceptable, which hampers their understanding of the natural world and its phenomena (CHASSOT, 2003; SANTOS, 2006).

For people to have access to scientific knowledge, places responsible for the construction of knowledge must be designed and built with quality and, if possible, with good availability of scientific resources. Jocobucci (2008) divided these places used for scientific training into two, namely informal places, characterized by a non-school environment, such as museums, parks and squares, and formal places, described as those within a school environment, such as the classroom and science laboratory.

Science laboratories have an important impact on the teaching-learning process, where they allow teachers to enrich their teaching and enable students to come in contact with materials presented in the classroom and in textbooks, enhancing the quality of science education (BEREZUK; INADA, 2010).

In the field of biological sciences, teaching entomology, a subarea of zoology dedicated to the study of insects, can be facilitated by the use of science laboratories for the observation and handling of animals. The study of insects is included directly or indirectly in the curriculum of both Elementary Schools and High Schools in Brazil, and it is an important area for students, so they can understand important aspects of human parasitology, agricultural pests and ecological processes, such as pollination of plants and the cycling of nutrients (SHEPARDSON, 2002; MATOS et al., 2009). However, some Brazilian school districts have, besides a lack of laboratories, a shortage of biological materials or models that represent them, making it impossible, therefore, to offer practical lessons on the subject.

Thus, this study aimed to describe the activities carried out by students of the Federal Institute of Education, Science and Technology Farroupilha in equipping the science laboratories of public schools in northwestern Rio Grande do Sul State with insect boxes for use by teachers in entomology practical. 
Scientific communication about the distribution of insect boxes in schools: report on experience

\section{ACCOUNT OF THE EXPERIENCE}

This outreach project was carried out by a team of 11 scholarship students and volunteers who were in the 3rd year of high school integrated with the technical education of the course of Maintenance and Support in Informatics at the Federal Institute of Education, Science and Technology Farroupilha, Panambi campus (IFFarroupilha), and by a student from the college course of Degree in Chemistry at the same institution.

Schools benefitting from the project were located in the cities of Panambi and Pejuçara, both in the northwestern region of Rio Grande do Sul State. The criteria adopted for selecting the institutions included being a public school and having at least one science laboratory for student use. In Panambi, the educational institutions chosen were the Poncho Verde State School of Basic Education, with 1,002 students enrolled, and the Pindorama State High School, with 650 students enrolled. In the municipality of Pejuçara, the selected school was the Angelo Furian State School of Basic Education, with approximately 300 students.

The project was carried out between March and December 2015 and was divided into three stages: 1st) planning and training of outreach team, 2nd) assembly of insect boxes and 3rd) delivery of insect boxes.

The first stage of the project was carried out in March 2015 and included the screening of outreach team and educational institutions that would benefit from the project. In addition, the team received basic training provided by the project coordinator in the areas of capture techniques, conservation, and mounting of the insects and their identification based on the information contained in published reports (Almeida; Ribeiro-Costa; Marinoni, 1998; Rafael et al., 2012).

The second stage was carried out between April and November 2015 and involved the collection of insects in the daytime and nighttime fortnightly from active captures (e.g., insect net) and passive captures (e.g., Shannon light trap). After being captured, the insects were placed in a killing tube and taken to the General Biology Laboratory of the institution to be mounted with entomological pins and dried for a period of 48 hours at $40^{\circ} \mathrm{C}$ in an incubator. Subsequently, the insects were identified on the basis of external morphological characters to the taxonomic level of order and then placed in insect boxes. In total, eight insect boxes were made, containing on average 25 insects (Figure). 


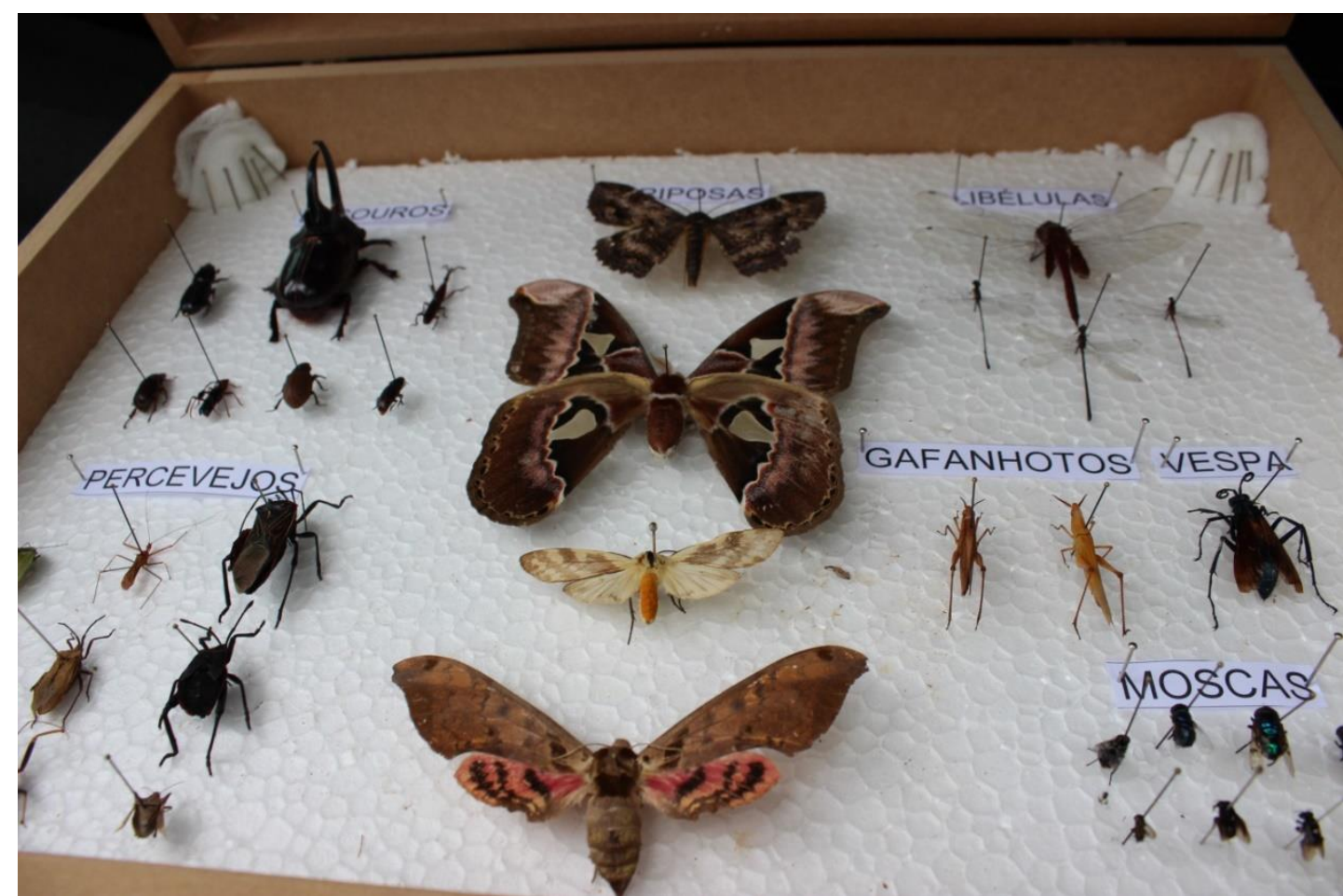

Figure - Insect box delivered to schools in Panambi and Pejuçara, Rio Grande do Sul, Brazil. Source: The authors.

The third stage of the project was conducted in December 2015 and involved the trip of the outreach team to the schools in four student groups, where they could learn about the science laboratories and deliver the insect boxes to the teachers responsible for science classes at the institutions. All boxes delivered to schools were displayed in the laboratories.

During the delivery of the insect boxes, the visiting students got to know the different situations of the schools and science laboratories and also were able to talk with the teachers and students of these places. On that occasion, the outreach team, during the interaction with the teachers who received the material, could explain the importance of insect boxes as a teaching tool in science class practical, which generated intense moments of reflection and construction of knowledge by teachers and the outreach workers themselves. This was observed from some comments made by the teachers, such as teacher R.M.O.L. who reported, "I loved this visit of students to our school. I thought the idea of insect boxes was very good and I plan to use them in my classes." Also, the teacher D.A.O. commented: "I will propose that the students also make insect boxes in the 7 th year when working in classes on arthropods." 
Scientific communication about the distribution of insect boxes in schools: report on experience

\section{FINAL CONSIDERATIONS}

The implementation of the project enabled the visiting students to learn more about entomology, since they experienced content that goes beyond what they work on in the classroom in their courses, especially in high schools. Also, by knowing the ways of a different school and exchanging experiences with teachers of the schools served by the project, the students were able to form more accurately a critical view of some aspects of science teaching in public schools in northwestern Rio Grande do Sul. On the other hand, from the point of view of educational institutions benefitting from this outreach project, we observed the precarious conditions of the science laboratory, with teaching resources being scarce and in poor condition, making quality laboratory practical in these environments impossible. In addition, teachers who received the insect boxes in the schools proved to be open to their use in their classes, which attests the importance of developing outreach projects that contribute to the expansion and quality of the teaching collections in science laboratories. Thus, projects of this nature can contribute to improving the scientific cultivation of students in public schools by encouraging practical approaches in the construction of knowledge.

\section{ACKNOWLEDGMENTS}

We are grateful to the Dean of Education and Research of the Federal Institute of Education, Science and Technology Farroupilha for financial support.

\section{REFERENCES}

ALMEIDA, L. M.; RIBEIRO-COSTA, C. S.; MARINONI, L. Manual de coleta, conservação, montagem e identificação de insetos. Ribeirão Preto: Holos, 1998.

BEREZUK, P. A.; INADA, P. Avaliação dos laboratorios de ciências e de biologia das escolas públicas e particulares de Maringá, Estado do Paraná. Acta Scientiarum. Human and Social Sciences, v. 32, n. 2, p. 207-215, Jul./Dec. 2010.

BROOKS, H. The relationship between science and technology. Research Policy, v. 23, n. 5, p. 477-486, Sep. 1994.

CHASSOT, A. Alfabetização científica: uma possibilidade para a inclusão social. Revista Brasileira de Educação, n. 22, p. 89-100, Jan./Apr. 2003. 
Scientific communication about the distribution of insect boxes in schools: report on experience

JACOBUCCI, D. F. C. Contribuições dos espaços não-formais de educação para a formação da cultura científica. Em Extensão, v. 7, n. 2, p. 55-66. 2008.

MATOS, C. H. C. et al. Utilização de modelos didáticos no ensino de entomologia. Revista de Biologia e Ciencias da Terra, v. 9, n. 1, p. 19-23, Jan. 2009.

RAFAEL, J. A. et al. Insetos do Brasil: Diversidade e Taxonomia. Ribeirão Preto: Holos, 2012.

SANTOS, W. L. P. dos. Letramento em química, educação planetária e inclusão social. Química Nova, v. 29, n. 3, p. 611-620, May. 2006.

SHEPARDSON, D. P. Bugs, butterflies, and spiders: children's understandings about insects. International Journal of Science Education, v. 24, n. 6, p. 627-643, Nov. 2010.

ZANCAN, G. T. Educação científica: uma prioridade nacional. São Paulo em Perspectiva, v. 14, n. 3, p. 3-7, Jul./Sep. 2000. 